\title{
Organizing Immigrant Workers in the Los Angeles Apparel Industry
}

\author{
by \\ Edna Bonacich \\ University of California, Riverside
}

Cite: Bonacich, Edna. (1998). "Organizing Immigrant Workers in the Los Angeles Apparel Industry." Journal of World-Systems Research http://jwsr.ucr.edu/4: 10 - 19.

(C) 1998 Edna Bonacich.

[Page 10]

Journal of World-Systems Research

Introduction: The U.S. Apparel Industry

The apparel industry in the United States is declining. Every month new reports are put out enumerating the loss of jobs. Meanwhile, parallel numbers report the monthly rise of imports. However, even though apparel jobs are moving offshore, U.S.based manufacturers and retailers still play a critical role in the production of apparel for the U.S. market. They have become multinational corporations. They now arrange for the production of their clothing in other countries, but they still remain in charge of ordering and marketing. 1

Unlike most multinational corporations with subsidiaries in developing countries, U.S. apparel firms usually do not purchase their own offshore plants. Instead, most develop arm's-length transactions with offshore contractors and licensees. The contractors produce the goods to be shipped back to the U.S. as imports, under specifications by the U.S. manufacturers and retailers. The licensees are more likely to produce for the local (offshore) market, paying the parent company royalties for the use of their brand name, and producing goods that meet the standards of the parent.

The driving force behind moving offshore is undoubtedly the search for lower-wage labor. U.S. apparel firms scour the world for the best deals that they can get. In general, they are moving to countries where peasants are being pushed off the land, and where very young women are being forced to enter the paid labor force as a first generation proletariat. These workers can suffer from multiple forms of control and oppression, including patriarchal family relations, brutal employers, and governments that deny their basic political rights. They are the most exploitable workers in the world. For many countries eager to industrialize, the apparel industry provides a first step as a low capital, 
labor intensive industry. Governments promise U.S. apparel manufacturers and retailers a controlled, trouble-free workforce for a fraction of U.S. wages. Of course, not all U.S. companies choose to move offshore, but the trend is for more of them to shift at least some of their production out of the country. Of the $\$ 178$ billion spent on apparel in the United States in 1995 , over half, or $\$ 91$ billion, was spent on imports, a figure that keeps rising each year. $\underline{2}$

The North American Free Trade Agreement has channeled some of this movement in the direction of Mexico. NAFTA's purposes, in part, were to enable U.S. apparel manufacturers and retailers to rely less on Asia and to develop their "own" low wage labor force within the Western Hemisphere. As a consequence, apparel imports from Mexico have soared, overtaking the major Asian exporters to the U.S., and promising to continue rapid growth.

\section{Los Angeles: The Great Exception}

In contrast to the rest of the United States, apparel employment has been growing in Los Angeles. Between 1993 and 1997 the LA industry added an estimated 26,000 new jobs. $\underline{3}$ The LA industry is now the largest apparel employer in the United States. True, New York still remains the chief fashion center of the nation, but jobs have shifted away from that city. Moreover, apparel is the largest manufacturing industry in Los Angeles, having surpassed the aerospace industry in the face of post-Cold War military cutbacks. Although the city is not as widely known for its apparel industry, that industry is just as large an employer as the movie industry, with an estimated 150,000 workers.

Los Angeles is mainly a center for the production of moderately priced, fashionable sportswear for women, especially young women or "juniors." LA's garments tend to be geared towards the spring and summer seasons. They are gaily colored, imaginative, reflecting the city's image of sunshine, beaches and informality. Some of the major apparel manufacturers are Guess? Inc, Bugle Boy, Rampage, Carole Little, Chorus Line, and $\mathrm{BCBG}$.

Not all LA apparel manufacturers do their production in Los Angeles. Some of them have almost all of their clothing produced offshore, while others outsource part of their production. However, some non-LA manufacturers have their production done in Los Angeles. One example is Designer Holdings, a New York based licensee for Calvin Klein Jeanswear, which uses LA contractors to sew many of its denim products.

Even if they produce their garments in Los Angeles, few manufacturers (or retailers) do their own production in-house. They make use of contractors, often many of them. There are literally thousands of garment contractors in Los Angeles, spread out across the basin. Most contractors are small businesses, employing an average of 35 workers, but a few have over 100 workers. These firms are typically assembly plants where workers sit at sewing machines and stitch together the cut materials that make up garments.

The Advantages to Manufacturers in the Contracting System 
The contracting system is touted by manufacturers for the flexibility it provides. Apparel manufacturing is unstable, since it is affected both by seasons and by shifts in fashion. The contracting system enables manufacturers to have work done only when they need it, thereby avoiding the maintenance of a stable labor force that they do not need year round. The contractors are able to absorb the changing demands of the industry, shifting their work among different manufacturers in an effort to keep their factories running at full capacity.

But there is another side to the contracting system. It also serves as a labor-control system. The contractors typically do the sewing or assembly. Some contractors specialize in cutting, laundering, or finishing, but the majority are assembly plants. By contracting out, the manufacturers externalize the labor. The manufacturer never loses title to the goods that the contractors sew. They do not sell the cut goods to the contractors. Instead, the contractors basically supply only the labor. They are essentially labor contractors.

As we have said, most contractors are small businesses. They are typically run by immigrant entrepreneurs who usually do not have much capital. Manufacturers are able to pit contractors against one another as they underbid each other to get the work. Contractors are typically offered a price for the work on a "take it or leave it" basis, because the manufacturer can always find another contractor who would be willing to do the work for less.

There is a substantial underground economy among apparel contractors. No one knows exactly how many shops operate without licenses or paying taxes, but estimates are that as many as one-third of all apparel factories fall into this sector. Some of the underground operations are small and operate out of people's garages, but some are substantial in size.

The small size and dispersion of apparel contracting firms in Los Angeles also means that they can fairly easily evade state inspection. The number of state inspectors does not remotely come close to the number that would be needed to police the industry systematically. Moreover, even when firms are caught with violations, they can go out of business and open again in a new location, under a new name.

[Page 11]

Journal of World-Systems Research

The contracting system enables labor costs to be kept at rock bottom levels. Meanwhile, manufacturers can deny any responsibility for conditions in their contractors' factories because they are "independent" businesses. They can place all the blame for conditions in these shops on the contractors, turning a blind eye to the fact that they set the low prices within which the contractors must operate. The fictional aspect of this claim is evident in the fact that manufacturers often send quality control people to the contractors on a daily basis, and keep a tight control over every aspect of production except labor standards. 
Another way that contracting serves as a labor control system is by inhibiting unionization. The work of a particular manufacturer is spread out over a number of factories. The workers in each of the factories do not even know of each other's existence. Indeed, since manufacturers are very secretive about the identity of their contractors, even the contractors may not know whom else works for "their" manufacturers. The dilemma for workers is that, given the low margins in the contracting shops, even if they should win a union struggle, it would be very difficult to get the contractor to pay higher wages. Moreover, the very act of trying to organize a factory is likely to lead the manufacturer to shift production away from that factory, and the workers would be left without jobs.

Workers are more likely to be successful if all the workers employed by contractors who work for the same manufacturer are able to find common cause. In other words, workers need to organize the entire production system of a single manufacturer simultaneously if they are to have any chance of success. Only then can they demand that the manufacturer face the demands for higher wages and benefits, since it is the manufacturer who profits most from their labor, and who has accumulated the surplus from which increases could be drawn. But the dispersion of the workforce into multiple, small factories makes coordination extremely difficult. It is in this sense that the contracting system is a wellhoned, anti-union device.

\section{The Workforce}

Garment workers in Los Angeles are uniformly immigrants. The majority are Latino, from Mexico and Central America, especially El Salvador and Guatemala. About ten percent are Asian, mainly from China and Southeast Asia, including Vietnam, Cambodia and Thailand. The largest group is Mexican. A large, unknown, number of garment workers are undocumented, without papers that legitimize their right to work in the United States. Most do not speak any English, and many have limited education in their homelands. The garment industry, along with domestic service, and to a lesser extent, the hotel and restaurant business, is a major employer of undocumented immigrants. Indeed, there is probably some preference for these workers because of their political vulnerability.

The majority of garment workers in Los Angeles are women. The 1990 census estimated that about 70 percent were women. Unlike the workers in the maquiladoras of Mexico and the Caribbean, LA's female labor force is not composed of teenagers. They are mainly young women in their 20s and 30s. Many are mothers, and some are the sole supporters of their families. The number of men working at sewing machines has grown in the last decade, probably as a consequence of the growing anti-immigrant sentiments and policies in California. As the crackdown on illegal immigration is stepped up, more immigrants are driven to take whatever jobs they can find. The garment industry remains a willing employer of the undocumented.

Undocumented immigrants are obviously especially vulnerable to exploitation, and their vulnerability is exacerbated in times of public, anti-immigrant fervor. Not only do they 
not have any of the usual legal recourse of citizens and permanent residents, but they are threatened with the possibility of exposure and deportation. Employers can use the fear this engenders to full effect. Workers can be intimidated into silence under a burden of oppression. Some garment workers are legal immigrants, but they rarely have the time to learn English and attain citizenship, so they remain without a vote or voice. In addition, the fact that most garment workers are women adds to the likelihood that they will face domination of various types by their employers.

\section{Conditions in the Shops}

There is some variation in the conditions in the garment contracting shops of Los Angeles, but overall conditions are remarkably similar. Garment workers typically work on piece rate, i.e., they are paid for each procedure they complete. This is similar to the pay system in agriculture, where farm workers are paid for the number of pounds they pick.

Both California and federal law require that workers be paid minimum wage and overtime even if they are paid piece rate. The employer needs to keep time cards and ensure that the hourly minimum wage is covered, and that, when employees work over eight hours a day (the law in California until recently), or 40 hours a week (federal and state law), they must be paid $1 \frac{1}{2}$ times their base wage. These regulations are routinely violated. Contractors want to pay only the flat piece rate, and they devise every trick in the book to hide the fact that that is what they are doing. They falsify the records, they maintain double books, they use double time cards, they cook up schemes so that overtime is calculated after the fact, they clock workers out after eight hours and pay them in cash thereafter, they have them work off the books on Saturdays, they encourage off-the-books homework, they get workers to kick back excess earnings in cash, and so forth. Thus minimum wage and overtime violations are extremely common in this industry. Even when workers are paid the legal minimum, garment workers remain among the lowest-paid workers in Los Angeles, and make up an important segment of the working poor.

A baseline survey of 69 California garment firms was conducted in 1994 by California and federal labor enforcement agencies. They found that 61 percent of Southern California firms failed to pay minimum wage and 78 percent failed to pay overtime. In addition, 74 percent had record-keeping violations and 41 percent paid workers in cash. 4 While subsequent surveys have found some diminution in some of these statistics, other areas show an increase in violations. The fact is violations of the law remain at an excessively high level.

[Page 12]

Journal of World-Systems Research 
The piecework system encourages self-exploitation, as workers work very fast and for as many hours as possible in order to make a living. It creates the illusion that the worker controls her earnings by her own skill-level, and makes it difficult for workers to feel a sense of common exploitation. The illusion of control is occasionally shattered, when workers are shifted to new tasks and find that their earning levels collapse, or when the contractor lowers the piece rate in a cost-cutting move. These kinds of actions are likely to trigger wildcat reactions on the part of workers, who feel that the rug has been pulled out from under them.

Homework is a fairly common feature in the LA apparel industry. Some workers are full time homeworkers, while others take work home after hours. While homework may sometimes be attractive to women workers, who combine work with childcare, it is typically associated with the lowest pay when all the worker's costs are added in. $\underline{5}$ None of the usual protections of minimum wage and overtime pay can be ensured because of the underground character of the work.

Garment workers rarely receive any fringe benefits whatsoever. They are typically not given paid vacations or paid sick leave. Medical insurance is virtually non-existent for the worker herself, and out of the question for her family. In other words, the system is geared towards paying workers their piece rate, and that is that. Note that, by not paying for the health care coverage of the workers in his contracting shops, the manufacturer, who can own a very profitable enterprise and be very rich himself, forces his workers to rely on the impoverished LA County health care system. Once again, the contracting system, by creating a false distance between the employer and his workers, enables the manufacturer to avoid taking responsibility, and forces the taxpayers to pick up what should rightfully be a tab that he pays.

Apart from poverty level wages, garment workers are also subject to other forms of abuse. Since garment contracting shops are small businesses, they lack bur eaucratic rules and are subject to the direct authority of the owner and supervisors. This authority can easily be conducted in an arbitrary fashion, with favoritism and discrimination. Workers who are not favored can be given older, less efficient machines, or can be denied work. They can also be subjected to personal abuse of all kinds, from being yelled at to facing sexual harassment. Workers will sometimes say that they can bear the harsh burden of low wages, but cannot endure being treated in an insulting and demeaning manner.

In addition, many garment factories in Los Angeles have serious health and safety violations. In a recent sweep it was found that 96 percent of factories violated the law, and 72 percent had such serious violations that they could result in injury or death. 6 The violations included such things as blocked fire exits, exposed wires, and machines without safety guards. Many of the garment shops of LA could turn into death traps in the event of a fire.

\section{The Return of Sweatshops}


We are in an era in which many government officials and others speak of a return of the sweatshop. In the U.S., garment industry sweatshops were more or less eradicated by a combination of the development of powerful garment worker unions, and the New Deal, which provided support for basic labor standards. Since the 1970s, and especially during the 1980s and 1990s, we have seen the erosion of wages and working conditions in the U.S. apparel industry. In 1950, average weekly wages of U.S. garment workers were 76.5 percent of the average manufacturing wage. By 1990, this figure had dropped to 54.1 percent. 7 Despite protests by industry leaders that only a few rotten apples run sweatshops, the reality is that problems are rampant throughout the LA industry.

Why are we seeing the return of sweatshops now? There are many reasons. Globalization certainly plays a critical role. Since apparel manufacturers and retailers can move, or threaten to move offshore, they force local workers to face the grim choice of accepting the jobs as they are, or losing the jobs altogether. Manufacturers and retailers can argue that they can get the work done offshore for a fraction of the price that they can get it done in Los Angeles. So any improvement in wages and working conditions is interpreted as a threat to the continuation of the industry in LA

[Page 13]

Journal of World-Systems Research

It is important to note that there are reasons why the industry has continued to grow in Los Angeles and has not all flown to cheaper labor sites. To a large extent, the LA industry specializes in fashionable clothing, where speed of production is more important than price. Moreover, the lot sizes are small, making them unsuitable for shipping offshore to large assembly plants that specialize in mass production. The small contracting factories of LA are uniquely suited to this kind of specialized production. Apart from that, there are agglomeration effects, where a manufacturer can meet all his production needs right in the vicinity.

While labor costs are clearly a factor in the decision to move offshore, the fact is that labor is only a relatively small percentage of the cost of apparel production. Especially in the realm of fashion and established brand names, what is being sold is more an "image" than the garment per se. Firms of this type spend millions of dollars on advertising, including celebrity endorsements, in order to create demand for a product that was relatively cheap to produce. Los Angeles is a city that specializes in image-creation, and so does its apparel industry. Rising labor costs is thus only one consideration in the decision to shift production.

This is not to say that the industry might not pack up and move to Mexico should the price of labor rise substantially. It may. Mexico is nearby, and Mexican firms may develop the capacity to engage in LA-style contracting. For the moment, they do not have this capacity so, despite a lot of bluster about leaving whenever a demand is placed on the industry to clean up its act, apparel production still continues to grow in Los Angeles. 
Globalization itself can be seen as part of a larger set of trends that have led to the return of sweatshops. These include the decline of the Welfare State and the attack on the labor movement. In general, we have been witnessing an effort on the part of big business to enhance its power, and to undermine the power of labor. Workers in the United States (and in other industrial nations) have gradually been stripped of the protections they were able to win in the post-World War II era. Various public programs and social assistance have eroded, unemployment has risen, and real wages have fallen. Meanwhile, business owners, along with the managers and professionals whom they employ, have grown richer and richer. The gap between rich and poor has grown wider. Los Angeles shows these trends even more starkly than the U.S. as a whole.

The first blast of attack against the labor movement occurred when Ronald Reagan became president and broke the Air Traffic Controllers strike. Since then, unions have faced the erosion of the legal environment that had been developed to protect workers' rights to organize during the New Deal. Unfair labor practices on the part of employers have become more flagrant as they have learned that the cost of union busting is minor compared to the cost of having to negotiate a union contract.

Another aspect in the growth of garment sweatshops has been the consolidation of retailing. Since the mid-1980s there has been a major merger movement in retailing, where giant retailers have bought each other out, assuming huge debt in the process. Some retailers have gone bankrupt. Others have become billion dollar giants who can exercise tremendous power over the industry. The United States has far too many stores per consumer, resulting in vicious competition. The retailers now have the power to pressure manufacturers to cut costs, change styles more rapidly, and maintain more inventory. 8 Many retailers themselves now have their own private (or store) label, where they employ their own contractors directly, bypassing the manufacturers altogether. They undercut the major brands, putting price pressure on them. All of this puts pressure down the line of the garment food chain, and the people most impacted by it are the workers, both in the U.S. and elsewhere.

Note that, although firms claim they must cut costs to remain competitive, the costcutting knife is rarely applied to the owners, managers and professionals in the industry. Executive salaries, advertising costs, profits, and similar rewards that go to the non-labor part of apparel production are allowed to soar with no outcry that these costs must be kept in check. The largest apparel manufacturers in Los Angeles are multi-millionaires. For example, six of the 100 highest paid executives in Los Angeles are in the apparel industry, and five of them work for one company: Guess? Inc. 20 Maurice Marciano, CEO of Guess, received $\$ 3.4$ million in salary and bonus in 1996. It is estimated that the three Marciano brothers, who own most of Guess, personally took home close to half a billion dollars over the last four years, including salaries, bonuses, distributions to stockholders, and the results of an Initial Public Offering.

[Page 14]

Journal of World-Systems Research 


\section{Ethnicity}

In Los Angeles, the apparel industry is structured along ethnic lines. The manufacturers are, for the most part, European in origins, though some are Middle Eastern and Asian. Jews play an important role at this level and, while some are immigrants, many are U.S.born. The contractors, in contrast, are almost all immigrants, as we have stated. They are from all over the world, but the plurality is Asian. Although Koreans are not numerically the most important, they run some of the largest shops and are very visible in the garment district.

The workers, as we have seen, are predominantly Latino immigrants. While there are some Latino contractors, the predominant pattern in the industry is for an Asian contractor to hire Latino workers. There are cases where contractor and workers are of the same ethnicity, and where there are paternalistic linkages between employer and employees. But this is the exception rather than the rule in Los Angeles. In LA, the relationship between contractor and worker tends to be strictly business-like. Exploitation is not softened by familial bonds or the bonds of helping someone from one's homeland.

This pattern of ethnic differentiation between contractors and workers makes Los Angeles different from other U.S. cities, and maybe other garment centers in Europe, too. In these places, although garment contractors and workers are also immigrants, they often come from the same country and share certain bonds of obligation. South Asians in Britain employ South Asians. Chinese in New York and San Francisco employ Chinese. And so forth. Obviously, some of this occurs in LA as well. Nor does it prevent exploitation. The infamous Thai "slave shop" of El Monte, uncovered in August 1995, involved Thai contractors employing Thai women workers.

The pattern found in Los Angeles is increasingly found in Mexico and the Caribbean, where Asian entrepreneurs from Korea and Taiwan are coming to countries like Guatemala and the Dominican Republic and hiring loc al Latino and indigenous workers. These firms serve as contractors for U.S. manufacturers and retailers. This pattern may also be spreading to other U.S. cities, such as New York.

The phenomenon of ethnic difference between the three layers of the industry: manufacturers as white, contractors as Asian, and workers as Latino, creates an important dynamic that spills over into the general race relations of the city. Considerable tension is developing between the Asian and Latino communities, since they meet at the front lines of an exploitative system. Meanwhile, the real economic powers, the manufacturers, retailers, real estate owners, bankers, etc., who are mainly native-born whites, do not have to deal with the antagonisms that arise in the workplace, even though they are primarily responsible for them. They can push the blame onto the immigrant entrepreneurs, making them out to be sleazy business operators who mistreat their workers, unlike the good old, decent, American businessman whom would never dream 
of running a sweatshop. Thus is racism fueled, and used to maintain current relations of power and privilege.

[Page 15]

Journal of World-Systems Research

\section{Efforts to Eliminate Sweatshops}

As the sweatshop scourge has grown, more government attention has be en devoted to trying to eliminate it. Both the state of California and the federal government have stepped up enforcement efforts. The dilemma is that catching a contractor often results in that particular firm going out of business, only to open up again in a new location under a different name. Since the manufacturers (and retailers) control the prices that set the conditions under which garment factories operate, the challenge has been to find a method to hold them responsible for what goes on in "their" factories.

The U.S. Department of Labor (DOL) has been especially innovative in trying to untangle this knot. They have used the principle of "hot goods" to force manufacturers to pay attention to the conditions under which their clothes are produced. Hot goods refers to the idea that goods made under illegal conditions cannot be shipped across state borders. In the highly time-sensitive fashion industry, invoking this provision made it imperative for manufacturers to make sure that their contractors could not be found engaging in illegal practices. The DOL was able to get a number of major manufacturers to sign agreements whereby they would undertake the monitoring of their contractors. These "compliance agreements" have forced the industry to develop comp liance programs under which private firms investigate their contractors to make sure that they are obeying the law.

Needless to say, questions get raised about the effectiveness of such an approach. It gets described as "the fox guarding the chicken coop." Even when manufacturers undertake the effort seriously, there are several problems. Workers are afraid to reveal violations for fear the contractor will fire them. Contractors are faced with the threat that the work will be taken away from them by the manufacturer, and while this threat may serve as an inducement for some to clean up their act, given the unchanged economics of the situation, for many it just means being more careful in hiding your misdeeds. The truth is, the only real sanction the manufacturer can use against the contractor is the "death sentence"--to stop shipping work, which will probably drive the contractor out of business. Since neither the contractor nor the workers want that, they both "conspire" to hide illegal practices from manufacturer monitors. Moreover, manufacturers themselves may turn a blind eye to problems among their contractors, since they do not want to disturb their production schedules. After all, their prices and practices created the problem in the first place. Their main motivation is to look clean so that the DOL will get off their backs. 
New proposals, from the White House Apparel Industry Partnership, for example, suggest the need for independent monitoring both within the U.S. and in the global apparel industry. There is a call to have NGOs and religious groups serve as monitors, so that the problems inherent in self-monitoring are avoided. However, given the years of experience contractors have had in hiding violations, one wonders whether independent organizations will be able to ferret out the problems.

\section{The Heart of the Matter}

At the root of the problem lies unequal power. The manufacturers and their allies have power and the workers have none. Not only do apparel manufacturers have all the usual sources of power in relation to their employees, but also in this case their relative power is exaggerated by the lack of citizenship rights of the workers. The garment industry in Los Angeles operates in many ways like the old U.S. South, or like the Apartheid regime in South Africa. Workers have no access to state institutions that provide the usual, minimalist protections. As an article in the Los Angeles Times stated concerning the recent mayoral election: "LA's mayor is elected by one city to govern another. The Los Angeles that elects the mayor--and other citywide office-holders--remains white and largely affluent; the city the mayor governs is predominantly non-white and largely poor." $10 \mathrm{LA}$ is now 43.5 percent Latino and 13.8 percent white, but Latinos make up less than 15 percent of the electorate.

Let me modify this point a little. LA garment workers do have some legal protections. They are entitled to minimum wage and overtime, and if state agents find that they have been underpaid, they have the right to receive back wages (even if they can rarely be collected). They also have the legal right to unionize (though being undocumented may hinder one's right to reinstatement if one gets fired for union activity). However, they remain highly vulnerable to actions that drastically hurt their interests, from the elimination of an eight-hour a day overtime provision in state law, to the curtailing of social services for their families, to stepped up sweeps by the Immigration and Naturalization Service. In contrast, if they are unhappy with certain policies, major manufacturers can call up the mayor or the governor. The mayor of Los Angeles has created an apparel industry panel, known as the California Fas hion Association, to protect and promote the industry, on which no representative of labor sits. The workers are voiceless.

Unionization is an answer to this situation. Workers need to organize and demand that their interests and needs be addressed. Unfortunately, the garment workers' union is exceedingly weak in LA, with only about 3,000 members. This has not always been the case historically, but union membership has eroded in the face of all the forces we have been describing.

[Page 16]

Journal of World-Systems Research 


\section{Approaches to Unionization}

The contracting system severely hampers union organizing efforts, as we have seen. If the workers in a contracting shop get organized, that factory will be boycotted by the manufacturers and will be driven out of business. Organizing in this industry thus requires special strategies. In particular, you need to bind the manufacturer into the union contract so that he pays enough to the contractors to cover union-level wages and benefits. He must be made to work only or predominantly with union shops that guarantee those wages and benefits. A union contract of this sort, known as a Jobber's Agreement, is the only form of "joint liability" that can succeed because it is guarded by the workers themselves. 11

How does one win such an agreement? In Los Angeles, apparel industry leaders are determined to withstand unionization at all costs. They do not want to concede an inch of their power. Thus the effort to unionize becomes a war, in which the union must hurt a company severely in order to drive it to negotiate. You practically have to drive the company out of business, and even then, some would rather die than work with a union.

However, the situation is ripe with dialectical possibilities. Every strength has its weaknesses and every weakness has its strengths. 12 Because the contracting system is based on loose ties between manu facturers and contractors, it is vulnerable to the disruption of production flows. For example, other manufacturers who use contractors in the same production system may agree, under pressure, to shift work away from a contractor with whom the union has a labor dispute, leaving the contractor more vulnerable to shutting down. The target manufacturer will have difficulty finding new contractors to work for him, especially in the middle of a labor dispute. In addition, truckers, who play a vital role in transporting goods in a dispersed production system, may support the garment workers by refusing to cross their picket line. In other words, the contracting system has its weaknesses in the face of organizing drives.

Contractors themselves are an interesting group in terms of unionization. On the one hand, it represents instant death for them if they are the only targets and they feel compelled to fight against. On the other hand, if the union is able to win a Jobber's Agreement, then they benefit from the higher prices and improved stability of the relationship with the manufacturer. In the long run they have an interest in unionization, but in the short run, they have a deadly opposition to it. However, preliminary agreements can sometimes be negotiated whereby they cooperate with the union in anticipation that the entire production system will be organized.

Apart from attempting to organize one manufacturer and its contractors as a single production system, other approaches are possible. One that is less threat ening to a manufacturer is the organizing of an entire sector at one time. In LA much of the industry falls into the amorphous category of "sportswear," but a few distinctive sectors stand out, such as denim, dresses, and swimwear. If enough resources can be mustered, an attempt could be made to organize all the manufacturers and contractors in that sector. 
Apart from attempting to hurt a company by interfering in its production flows--a process that can be vital to the time-sensitive apparel industry, unions have learned that companies are vulnerable in the non-production aspects of their operations. Sometimes called corporate campaigns, the idea is to examine all the relationships and plans of the company for their pressure points. These include relationships with financial agents, with distributors and retailers, and with community groups and consumers. In the case of fashion, where image contributes so much to the value of the product, an attack on the image of a company can be very damaging.

One of the advantages of corporate campaigns is that they can follow a company offshore. If an apparel manufacturer flees the accusation that they are using sweatshops in the U.S., they can equally be accused of exploiting workers in other countries. Since the clothes are still sold by U.S. retailers to U.S. consumers, those consumers can be as outraged about conditions for workers in Vietnam and Guatemala as they are about conditions in Los Angeles. Indeed, some very successful campaigns have been waged against companies who exploit abroad. True, they have generally not been union organizing campaigns, but they have certainly revealed the weaknesses of firms to this kind of negative publicity.

[Page 17]

Journal of World-Systems Research

Needless to say, corporate strategies are all adjuncts to worker organizing. Aroused workers cannot win a campaign without having a strategy that is based on a thorough understanding of the industry's dynamics. But on the other hand, a union cannot win such a campaign without worker support and involvement. The two must go hand in hand.

Organizing such vulnerable workers is a formidable task. Some romanticize the situation by claiming the immigrants are on the brink of militancy. Certainly there have been some noteworthy immigrant worker movements in LA, such as the drywallers' strike, but the immigrant workforce can hardly be described as ready for a general strike--devastating though that would be to the local economy. Garment workers are surely aware of their oppression and do sometimes engage in spontaneous protest against egregious actions on the part of their employers. But their poverty and political vulnerability make it very difficult for them to take risks.

For this reason, other types of organizing apart from direct union organizing in a campaign to win a contract have arisen. These include community-based efforts that try to engage in basic worker education and service. UNITE, for example, has worked with the idea of a Justice Center that encourages participation by garment workers no matter what labels they are sewing. Ethnic communities have also developed their own outreach to aid and educate workers from their particular communities. Much more could be done to lay the basic groundwork for more militant struggles. Even so, being prepared to fight back is not enough. The challenge is to learn not only how to fight, but how to win. 


\section{The Guess Campaign}

UNITE is currently engaged in an effort to organize the largest LA garment manufacturer, Guess? Inc. Guess is a company that has s ales of over $\$ 500$ million per year. It is a highly profitable company that can certainly afford to pay its workers a living wage. The company is super anti-union and has used every trick in the book to try to break the union, from firing union sympathizers, to organizing anti-union demonstrations, to litigating every point it can. If the Marcianos only spent a fraction of what they pay for their high-priced lawyers, public relations firms, and union-busting consultants on supplementing workers' wages, the workers in their contracting shops would make a living wage. Needless to say, their anti-union activism receives strong endorsement from the rest of the industry, which fears the opening of a door that would transform the power relations in the industry for them all.

So far the union campaign has involved multiple tactics. Apart from organizing workers both in Guess's inside shop, where they employ cutting and warehouse workers, and in their contracting shops, the union has been able to show that violations, including illegal homework, are rampant in Guess's contracting network. Guess was the first apparel firm to sign a self-monitoring compliance agreement with the DOL, and it is clear that they have not been able to eliminate sweatshops from their own production network. The union has also put pressure on Guess's own retail stores, consisting of boutiques in up scale malls where private property rights protect stores against social protest. And it is building a major campaign against the department stores that carry Guess clothes.

Of course, there are those who argue that unionization will push the industry more quickly to move all of its production to Mexico. Guess has already moved some of its production there, though its management denies that this has any thing to do with union organizing. No doubt some movement south would result if garment workers became organized, although it seems likely that certain sectors will remain, at least for a while. Besides, the cost pressure from organized workers may drive some manufacturers to seek new technologies and labor systems that are less dependent on sweated labor. These technologies and labor systems are being experimented with in the U.S. south, where a labor shortage is driving up wages to some degree. Finally, the movement of at least parts of the industry south may compel UNITE to develop a full-fledged cross-border organizing effort, to the benefit of workers on both sides of the border.

[Page 18]

Journal of World-Systems Research

\section{Conclusion}

A bright spot in the current organizing efforts among immigrant workers in Los Angeles is the growing recognition that workers and unions cannot go it alone. They need strong community support. Community and religious groups are playing a more active role in 
denouncing sweatshop practices, and demanding that manufacturers and retailers be held accountable for the conditions under which their clothes are made. Consumers, in particular, can send a warning to the industry by refusing to buy sweatshop-made goods. Clothes that are produced in Mexico are mainly shipped back for sale in the U.S., and U.S. consumers can express their outrage at an industry that seeks out the cheapest labor in the world by being very careful about what they buy.

However, rather than support a general boycott against all firms that rely on sweatshops, which would encompass virtually every apparel manufacturer, consumer and community pressure is most effective when it is focused, and used in support of a workers' movement. For example, community groups can help to put pressure on Guess as a means of supporting the workers who toil in Guess contracting shops by not purchasing Guess products, and also by joining with workers in actions and demonstrations that call for union recognition.

Some believe that the LA apparel industry cannot be organized. It is too slippery a fish. The relationship of forces is so negatively skewed against the garment workers that they may as well give up and get by as best they can. I do not accept such fatalism. Garment workers are among the most oppressed and exploited people in our city. Their struggle requires the support of everyone. If they receive it, they will prevail.

Los Angeles

July 24, 1997

\section{Endnotes}

1 Presented at the annual conference of the American Sociological Association in Toronto, Aug 9-13, 1997.

2Edna Bonacich, Lucie Cheng, Norma Chinchilla, Nora Hamilton and Paul Ong, Global Production: The Apparel Industry in the Pacific Rim. Philadelphia: Temple University Press, 1994.

3American Apparel Manufacturers Association, Focus: An Economic Profile of the Apparel Industry. Arlington, VA, 1996, p.4.

4Jack Kyser, "Manufacturing in Los Angeles." LA: Economic Development Corporation, June 1997, p.4.

5Targeted Industries Partnership Program (TIPP), Fourth Annual Report, 1996, p.18.

6Rosa Marta Fregoso, The Invisible Workforce: Immigrant Home Workers in the

Garment Industry of Los Angeles. Berkeley: University of California, MA in Latin American Studies, 1988. 


\section{TIPP op cit.}

8American Apparel Manufacturers Association, Focus: An Economic Profile of the Apparel Industry. Arlington, VA, 1993, pp.19-20.

9Laura Bird and Wendy Bounds, "Stores' demands squeeze apparel companies." Wall St Journal 7/15/97, B1.

$\underline{10 B e n ~ S u l l i v a n, ~ " B a n k e r s, ~ f i n a n c i e r s ~ d o m i n a t e ~ r a n k s ~ o f ~ L A ' s ~ h i g h e s t ~ p a i d . " ~ L o s ~ A n g e l e s ~}$ Business Journal 6/23/97, p.1.

11Tim Rutten and Peter Y. Hong, "For candidates, race relations a complex issue." LA Times 3/30/97, Al.

12 Of course, this kind of contract does not guarantee that either the workers or union officials will actively defend it. The constant political involvement of the workers is a precondition to maintaining such institutions, especially in an environment where the manufacturers and contractors are continually trying to undermine them.

13 I learned, with gratitude, some of these ideas from David Young, director of organizing of the ILG (International Ladies Garment Workers Union) in LA before it merged with ACTWU (Amalgamated Clothing and Textile Workers Union) to form UNITE (Union of Needletrades, Industrial and Textile Employees).

[Page 19]

Journal of World-Systems Research 